\title{
Influence of Natural Dyes on Surface Roughness of Eastern Redcedar
}

\author{
"Osman Goktas ${ }^{1}$, Mehmet Yeniocak ${ }^{1}$ \\ ${ }^{1}$ Department of Woodworking Industrial Engineering, Faculty of Technology, Mugla Sitki Kocman \\ University, Kotekli,/Mugla 48000 -Turkey \\ *Corresponding author: E mail: ogoktas@mu.edu.tr
}

\begin{abstract}
Gelis Tarihi:10.03.2016
Abstract

The objective of this study was to evaluate surface quality of Eastern redcedar (Juniperus virginana L.) samples finished with natural dye produced from the Madder root (Rubia tinctorium L.] with two kinds of mordants, ferrous sulfate $\left(\mathrm{Fe}_{2}\left(\mathrm{SO}_{4}\right)_{3} .7 \mathrm{H}_{2} \mathrm{O}\right)$ with technical grade $96 \%$ purity, supplied by Merck and alum $\mathrm{KAl}_{2}\left(\mathrm{SO}_{4}\right)_{3} \cdot 18 \mathrm{H}_{2} \mathrm{O}$ (puriss. p.a. Fulka). Surface roughness of the control and finished samples were measured employing a fine stylus type profilometer resulted in two parameters, namely average roughness (Ra) and mean peak-to-valley height $(\mathrm{Rz})$. Finishing materials were applied to the surface of the samples by soaking with and without using ultrasound in a tank. Average value of Ra taken from the surface of unfinished control samples and finished samples were $2.60 \mu \mathrm{m}$ and $3.25 \mu \mathrm{m}$, respectively. It appears that natural dye with alum and ferrous sulfate used as dying materials did not adversely influence overall surface quality of the samples. Based on the initial findings in this work such root dye would have potential as ecofriendly non-toxic colorant to extend the service life of product manufactured from Eastern redcedar.
\end{abstract}

Keywords: Eastern redcedar, root dye, surface roughness

\section{Özet}

Doğal Boyaların Kırmızı Doğu Sediri Yüzey Pürüzlülüğüne Etkisi

$\mathrm{Bu}$ çalışmanın amacı; kökboya'dan elde edilen boya ve iki tip mordan karışımları (demir sülfat $\left(\mathrm{Fe}_{2}\left(\mathrm{SO}_{4}\right)_{3} .7 \mathrm{H}_{2} \mathrm{O}\right)$ ve alüminyum sülfat $\left.\mathrm{KAl}_{2}\left(\mathrm{SO}_{4}\right)_{3} \cdot 18 \mathrm{H}_{2} \mathrm{O}\right)$ ) ile boyanan kırmızı doğu sediri (Juniperus virginana L.) türünün yüzey kalitesinin değerlendirilmesidir. Elde edilen boyar madde ve mordan karışımları deney örneklerine klasik daldırma ve ultrasonik yöntem kullanılarak uygulanmıştır. Boyanan ve kontrol grubu örneklerinin, ince kalem tipi profilometre kullanılarak, ortalama pürüzlülük (Ra) ve ortalama pürüzlülük derinliği (Rz) değerleri ölçülmüştür. Boyasız kontrol ve boya uygulanmış numunelerin yüzeylerinden alınan Ra ortalama değerleri sırasıyla $2.60 \mu \mathrm{m}$ ve $3.25 \mu \mathrm{m}$ olarak kaydedilmiştir. Kökboya ve alüminyum sülfat ile demir sülfat karışımı kullanılarak renklendirilen örneklerin yüzey kalitesinin olumsuz olarak etkilenmediği gözlemlenmiştir. Sonuç olarak; daha uzun ömürlü, toksik olmayan ve çevre dostu bir ürün olarak kökboyanın kırmızı doğu sedirimden üretilen ürünlerin boyanmasında potansiyel bir malzeme olabileceği düşünülmektedir.

Anahtar kelimeler: Kırmızı doğu sediri, kökboya, yüzey pürüzlülüğü

\section{Introduction}

Protective finishing, coating, paints are commonly used in the form of formulation with certain solvents or volatile organic compounds (VOC) to improve stability and overall performance of wood products. Volatile organic compounds which are used as wood finishing material play an important role on the quality of indoor air. Wood based furniture industry uses coating and dyeing products which emits more than 150 types of chemicals and volatile organic compounds (VOC) into the environment (Goktas et al. 2009a; Singh et al. 2005; Angelini et al.1997). Increase awareness of health risk and overall quality of indoor air has led to a demand for finishes and paints with lower VOC content. Similar to paints, clear varnishes used in furniture production could also have more prominent effect than that of regular paints on the air quality. Toxic pollutants such as xylene and toluene that are widely used solvents may be carcinogenic (Goktas et al. 2009b; Goktas et al. 2008). Additionally solvents derived from petroleum based materials used for manufacture of different types of lacquers, varnishes and sealers can also have some toxicity. Therefore it is important to control VOC levels of finishes used in wood products industry specifically in furniture manufacture. One of the approaches to achieve this would be using synthetic formulations which contain low VOC. However it appears that naturally derived formulations that use natural pigments is ideal method to reduce VOC level. Therefore there is growing demand for ecofriendly non-toxic dyes as finishing raw 
material in wood products industry to control VOC level (Goktas et al. 2009b; Tsatsaroni et al. 1998).

Natural pigments are commonly used to color art and craft items, carpets, wood, silk, fabric, leather and other materials in traditional ways in many countries (Billmeyer 1991; McLaren 1983). Red dye which is produced from the root of Madder species belonging to the Rubiaceae plant family has been used for such purposes for many years (Davis 1982). The dye has a long history of medical use as herb and skin ailment. It can grow $1.5 \mathrm{~m}$ height with evergreen leaves having $5 \mathrm{~cm}-10 \mathrm{~cm}$ length. The roots can be over a meter long with around $1 \mathrm{~cm}$ diameter. The pulverized roots can be dissolved in sulphuric acid, alkaline or alcohol resulting in red color dye known as madder. Plant is widely available in Mediterranean countries including Turkey (Davis 1982). The dye can be produced from the roots which have been crushed and hulled. The most commonly used production method is to extract the dye by soaking hulls in water at low temperature having with or without alcohol and alkaline solvents.

Eastern redcedar (Juniperus virginiana $L$.) is one of the most widely distributed indigenous conifers in Oklahoma (Hiziroglu and Holcomb 2002; Hiziroglu and Holcomb 2005). The largest areas of recent expansion have been in the southwestern part of the state, characterized by an arid climate and rocky soils, and the northwestern part of the state, primarily open prairie land dissected by waterways. It is concerned that encroaching redcedars may someday capture over the tall grass prairies in northern Oklahoma Acreage of eastern redcedar in Oklahoma, with the exception of the Panhandle, exceeds seven million acres (Hiziroglu and Holcomb 2005). Use of lowquality eastern redcedar as a raw material in lumber manufacturing is not substantial due to its low value and irregular growth pattern. Eastern redcedar is a problem to farmers and ranchers who often lose crop and pasture land to the species. The trees are generally considered a water-stealing and space-taking nuisance. Many wildlife species that require open range also are adversely affected by this species. Currently the wood from eastern redcedar is used for fence posts and novelty items, while the species maybe planted for shelterbelts and windbreaks. Production of novelty items and paneling material from large trees is still in demand.

In generally surface quality plays an important role to control amount of finishing applied to the members and overall quality of finished product. It is fact that rougher surface of a substrate will not only require larger amount of finishing material but also lower quality of finished member. There are various methods to evaluate surface quality of wood and wood products but stylus method was successfully used to evaluate surface roughness both solid wood and wood composite samples in past studies (Hiziroglu 1996; Hiziroglu and Holcomb 2002; Hiziroglu et al. 2008; Satoshi andHiziroglu 2010).

Most of properties of Eastern redcedar have been investigated in a past study (Forest Product Laboratory 1992). However there is no or a very little information on finishing characteristics of Eastern redcedar finished with eco-friendly dyes, and effect of this kind of dyes on their surface quality. Therefore the main objective of this study was to use Eastern redcedar which is invasive and underutilized species as substrate for dyeing with products manufactured from natural dye and evaluate its influence on surface roughness of the finished material so that both underutilized materials, substrate and dye can be used more effectively.

\section{Material and Method}

A total of 48 defect free Eastern redcedar samples with dimensions of $22 \mathrm{~mm}$ by $27 \mathrm{~mm}$ by $50 \mathrm{~mm}$ having tangential grain orientation were prepared for the tests. Surface of each sample was manually sanded with 150 grits sand paper applying several light strokes. The specimens were conditioned in a climate chamber with a temperature of $21^{\circ} \mathrm{C}$ and a relative humidity of $65 \%$ until they reach to an equilibrium moisture content of $12 \%$ prior to any finishing application.

Madder Roots (Rubia tinctorium L.) was supplied from a commercial company in Milas/Mugla. Mordant agents; Ferrous sulphate $\left(\mathrm{Fe}_{2}\left(\mathrm{SO}_{4}\right)_{3} .7 \mathrm{H}_{2} \mathrm{O}\right)$ and aluminum sulphate $\left(\mathrm{Al}_{2}\left(\mathrm{SO}_{4}\right)_{3} .18 \mathrm{H}_{2} \mathrm{O}\right)$ were provided from Kimetsan Co.

\section{Preparation of dyestuff}

A weighed amount of dry plant material was extracted with distilled water in a ultrasonic bath (Elmasonic X-tra $150 \mathrm{H}$ ). Ultrasound-assisted extraction is an inexpensive, simple and efficient alternative to conventional extraction techniques. The main benefits of use of ultrasound in solid- 
Six measurements with a tracing span of 15.2 extraction yield and faster kinetics. Ultrasound can also reduce the operating temperature allowing the extraction of thermolabile compounds. Compared with other novel extraction techniques such as microwaveassisted extraction, the ultrasound apparatus is cheaper and its operation is easier (Wang and Weller 2006). In literature it was also found that ultrasound enhanced the penetration of the dye into porous structure of wood (Sivakumar and Rao 2003; Sivakumar et al. 2009).

In the standard procedure the ratio of mass of plant material to the volume of liquid was $1: 20$; extraction was performed for approximately. Extraction performed 180 min. time, $45{ }^{\circ} \mathrm{C}$ temperature and $180 \mathrm{~W}$ sonic power in a stainless ultrasonic bath. Due to the rather high liquor ratio some manual stirring was sufficient to distribute the plant material in the liquid during the extraction period. Volume loss due to evaporation was compensated by the addition of water at the end of the extraction period to obtain the initial volume.

Aqueous solutions were mordanted by adding ferrous sulphate $\left(\mathrm{Fe}_{2}\left(\mathrm{SO}_{4}\right)_{3} .7 \mathrm{H}_{2} \mathrm{O}\right)$ $3 \%$ and aluminum sulphate $\left(\mathrm{KAl}_{2}\left(\mathrm{SO}_{4}\right)_{3} .18 \mathrm{H}_{2} \mathrm{O}\right) 5 \%$ in order to stabilize the color of dyes extracted, to ensure it to hang on the applied material (to increase retention amount), and to create color options.

\section{Treatment}

The air-dried wood specimens were placed into ultrasonic bath container according to their intended treatments. Two different methods (immersion and ultrasonic-assisted immersion) of dyeing were used. Treatment was performed for ultrasonic-assisted immersion method; 60 min. time, $45^{\circ} \mathrm{C}$ temperature and $300 \mathrm{~W}$ sonic power, for immersion method $60 \mathrm{~min}$. time, 45 ${ }^{\circ} \mathrm{C}$ temperature in a stainless ultrasonic bath.

\section{Surface Roughness Tests}

Unfinished control samples along with control were also kept in a room temperature for three days prior any roughness measurements were taken from their surfaces. $\mathrm{mm}$ were taken from both sides of the samples across grain orientation by employing a stylus type Hommel T-500 profilometer before and after treatment of the samples. Stylus unit used in this study consists of the main unit and the pick-up model TkE. The pick-up has a skid type diamond stylus with $5 \mu \mathrm{m}$ tip radius and a $90^{\circ}$ degree tip angle. The stylus traverses the surface at constant speed of $1 \mathrm{~mm} / \mathrm{sec}$ over $15.2 \mathrm{~mm}$ tracing length, covering the vertical displacement of the stylus into an electrical signal. The calibration of the instrument was checked every 100 measurements by using a standard reference plate with $R_{a}$ values of 3.02 $\mathrm{p}, \mathrm{m}$ and $0.48 \mathrm{p}, \mathrm{m}$. A cut-off length of $2.54 \mathrm{~mm}$, a parameter that differentiates roughness and waviness profiles from each other was used for the test (Hiziroglu andHolcomb 2005; Hiziroglu et al. 2008).

A total of six measurements with a span of 15 $\mathrm{mm}$ were taken from both tangential surfaces of the samples across the grain orientation $n$ before and after they were soaked into dye solutions. Two roughness parameters average roughness (Ra) ad mean peak-to- valley height (Rz) were considered to evaluate the effect of dyeing on surface roughness of the samples. Roughness measurements were analyzed by using ANOVA test to determine if there is any significant difference between surface quality of the samples before and after treatment using regular soaking and ultrasound soaking in the solutions. Figures 1 and 2 illustrate dye in particle form and dyed samples, and typical roughness profiles of the samples, respectively.

\section{Results and Discussion}

Table 1 shows average roughness values of the control samples and those treated with red dye with combination of various chemicals. Samples soaked in water had an average $\mathrm{R}_{\mathrm{a}}$ value of 3.16 um which is only $8.9 \%$ higher than that of control sample. Combination of water and red dye applied to the surface of the samples also resulted in almost similar value. Surface of the sample was dyed with ferrous sulfate $\left(\mathrm{Fe}_{2}\left(\mathrm{SO}_{4}\right)_{3} .7 \mathrm{H}_{2} \mathrm{O}\right)$ and alum $\left(\mathrm{KAl}_{2}\left(\mathrm{SO}_{4}\right)_{3} \cdot 18 \mathrm{H}_{2} \mathrm{O}\right)$ along with rubia dye staff in both single and double times dyeing did not show any significant difference from each other.

Table 1. Average roughness and mean peak-to-valley values of the samples 


\begin{tabular}{|c|c|c|c|c|c|c|c|c|c|}
\hline & & \multicolumn{8}{|c|}{ Roughness Parameters $(\mu \mathrm{m})$ Dyeing methods } \\
\hline & & \multicolumn{8}{|c|}{ Application methods } \\
\hline & & \multicolumn{4}{|c|}{ Immersion } & \multicolumn{4}{|c|}{ Immersion + Ultrasound } \\
\hline & & \multicolumn{2}{|c|}{$\mathrm{Ra}$} & \multicolumn{2}{|c|}{$\mathrm{Rz}$} & \multicolumn{2}{|c|}{$\mathrm{Ra}$} & \multicolumn{2}{|c|}{$\mathrm{Rz}$} \\
\hline Treatment & & $\begin{array}{c}\text { Before } \\
\text { treatment }\end{array}$ & $\begin{array}{c}\text { After } \\
\text { treatment }\end{array}$ & $\begin{array}{c}\text { Before } \\
\text { treatment }\end{array}$ & $\begin{array}{c}\text { After } \\
\text { treatment }\end{array}$ & $\begin{array}{c}\text { Before } \\
\text { treatment }\end{array}$ & $\begin{array}{c}\text { After } \\
\text { treatment }\end{array}$ & $\begin{array}{c}\text { Before } \\
\text { treatment }\end{array}$ & $\begin{array}{c}\text { After } \\
\text { treatment }\end{array}$ \\
\hline \multirow{3}{*}{ With water } & Mean & 2.90 & 3.16 & 21.52 & 19.77 & 2.84 & 3.31 & 21.32 & 23.55 \\
\hline & $\mathrm{N}$ & 5 & 5 & 5 & 5 & 5 & 5 & 5 & 5 \\
\hline & S.D. & 0.62 & 0.11 & 5.43 & 3,38 & 0.72 & 0.16 & 5.44 & 1.24 \\
\hline \multirow{3}{*}{$\begin{array}{c}\text { Water + paint } \\
\text { (without mordant) }\end{array}$} & Mean & 2.52 & 3.13 & 18.14 & 22.33 & 2.68 & 3.60 & 17.46 & 23.15 \\
\hline & $\mathrm{N}$ & 5 & 5 & 5 & 5 & 5 & 5 & 5 & 5 \\
\hline & S.D. & 0.35 & 0.40 & 2.77 & 2.40 & 0.79 & 0.92 & 2.97 & 1.84 \\
\hline \multirow{3}{*}{$\begin{array}{l}\text { Aluminum sulfate }+ \text { single } \\
\text { immersion into dyeing } \\
\text { stain }\end{array}$} & Mean & 2.50 & 3.51 & 18.48 & 24.83 & 2.94 & 3.87 & 21.70 & 27.06 \\
\hline & $\mathrm{N}$ & 5 & 5 & 5 & 5 & 5 & 5 & 5 & 5 \\
\hline & S.D. & 0.72 & 0.40 & 4.71 & 2.38 & 0.58 & 0.45 & 7.45 & 2.56 \\
\hline \multirow{3}{*}{$\begin{array}{l}\text { Ferro sulfate }+ \text { single } \\
\text { immersion into dyeing } \\
\text { stain } \\
\end{array}$} & Mean & 2.00 & 3.17 & 18.62 & 21.70 & 2.70 & 3.33 & 21.15 & 23.03 \\
\hline & $\mathrm{N}$ & 5 & 5 & 5 & 5 & 5 & 5 & 5 & 5 \\
\hline & S.D. & 0.41 & 0.55 & 2.13 & 2.57 & 0.12 & 0.17 & 2.25 & 1.23 \\
\hline \multirow{3}{*}{$\begin{array}{c}\text { Aluminum sulfate }+ \text { double } \\
\text { immersion into dyeing } \\
\text { stain }\end{array}$} & Mean & 2.44 & 3.31 & 18.66 & 23.56 & 3.12 & 3.37 & 17.66 & 25.10 \\
\hline & $\mathrm{N}$ & 5 & 5 & 5 & 5 & 5 & 5 & 5 & 5 \\
\hline & S.D. & 0.41 & 0.31 & 2.74 & 2.09 & 1.70 & 0.30 & 4.08 & 3.76 \\
\hline \multirow{3}{*}{$\begin{array}{l}\text { Ferro sulfate }+ \text { double } \\
\text { immersion into dyeing } \\
\text { stain }\end{array}$} & Mean & 2.70 & 3.23 & 11.67 & 22.35 & 2.53 & 3.01 & 18.32 & 21.20 \\
\hline & $\mathrm{N}$ & 5 & 5 & 5 & 5 & 5 & 5 & 5 & 5 \\
\hline & S.D. & 0.81 & 0.54 & 3.29 & 3.38 & 0.25 & 0.11 & 3.13 & 0.33 \\
\hline \multirow{3}{*}{ Total } & Mean & 2.60 & 3.25 & 18,85 & 22.42 & 2.80 & 3.41 & 19.60 & 23.85 \\
\hline & $\mathrm{N}$ & 30 & 30 & 30 & 30 & 30 & 30 & 30 & 30 \\
\hline & S.D. & 0.55 & 0.40 & 3.60 & 2.96 & 0.81 & 0.49 & 4.55 & 2.69 \\
\hline
\end{tabular}

S.D.= Standard Deviation, $\mathbf{R a}=$ Arithmetic average of absolute values, $\mathbf{R z}=$ Average distance between the highest peak and lowest valley in each sampling length, $\mathbf{N}=$ Number of samples

Table 1 also displays Ra and Rz values of the samples before and after dyeing with different treatments.

Eastern redcedar has oil content in its wood ranging from 1 to $3.8 \%$. Having smooth surface quality of the sample even they are treated with solution having red dye with chemical would possibly related to oil content of eastern redcedar which may enhance hygroscopicity of wood. In a another study surface quality of eastern redcedar exposed to heat treatment also resulted in smoother surface quality due to extractives and oil in the wood (Kasemsiri et al. 2012). Tables 2 and 3 also display statistical analysis showing that no significant difference was found between surface roughness measurements of the sample as function of various treatments.

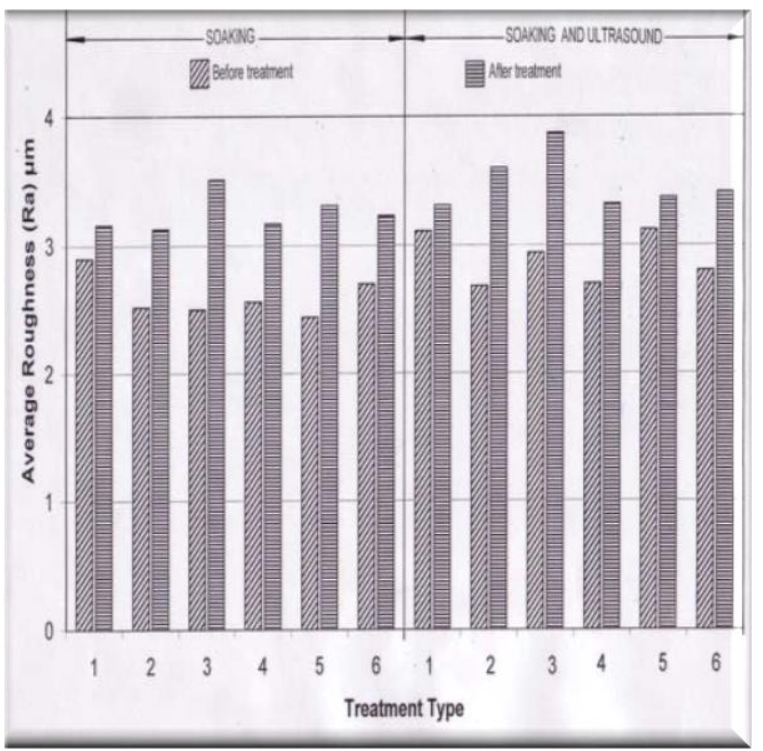

Figure 1. Average Roughness (Ra) 


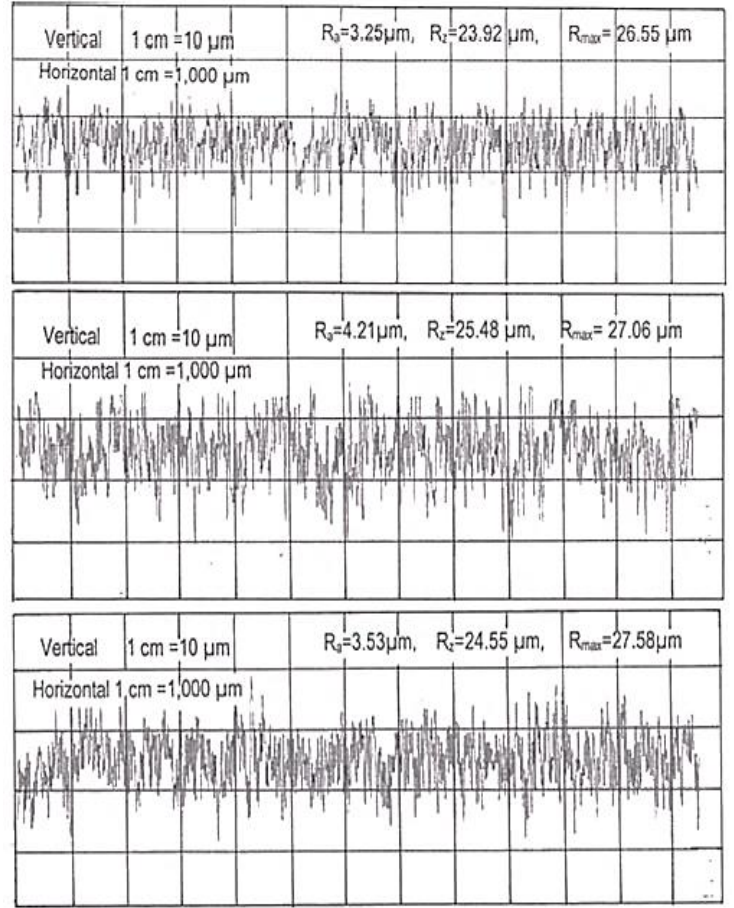

Figure 2. Typical roughness profiles of the samples
In general surface quality of wood coated with oil based system varnishes or paint shows smoother surface. However one would expect water based natural dye used in this work should reduce surface quality of the samples which is not the case. In this work samples were treated using two methods, namely soaking and exposing them to ultrasound when they are soaked in the chemicals. For example even the samples treated with ferrous sulfate and double layer paint had only $3.7 \%$ increase in their Ra value when they are exposed to ultrasound.

Table 2. Paired samples statistical values

\begin{tabular}{|c|c|c|c|c|c|c|}
\hline & & \multicolumn{5}{|c|}{ Paired Samples Statistics } \\
\hline \multicolumn{3}{|l|}{ Application methods } & Mean & $\mathrm{N}$ & S.D. & Std. Error Mean \\
\hline \multirow{4}{*}{ Immersion } & Before treatment & \multirow{2}{*}{$\mathrm{Ra}$} & 2.60 & 30 & 0.55 & 0.10 \\
\hline & After treatment & & 3.25 & 30 & 0.40 & 0.07 \\
\hline & Before treatment & \multirow{2}{*}{$\mathrm{Rz}$} & 18.85 & 30 & 3.60 & 0.66 \\
\hline & After treatment & & 22.42 & 30 & 2.96 & 0.54 \\
\hline \multirow{4}{*}{ Immersion + Ultrasound } & Before treatment & \multirow{2}{*}{$\mathrm{Ra}$} & 2.80 & 30 & 0.81 & 0.15 \\
\hline & After treatment & & 3.41 & 30 & 0.49 & 0.09 \\
\hline & Before treatment & \multirow{2}{*}{$\mathrm{Rz}$} & 19.60 & 30 & 4.55 & 0.83 \\
\hline & After treatment & & 23.85 & 30 & 2.69 & 0.49 \\
\hline
\end{tabular}

Table 3. ANOVA test values of the roughness measurements of the specimens

\begin{tabular}{|c|c|c|c|c|c|c|c|c|c|c|}
\hline & & & & & & Paired Di & ferences & & & \\
\hline & & & Mean & S.D. & $\begin{array}{c}\text { Std. } \\
\text { Error }\end{array}$ & $\begin{array}{r}95 \% \mathrm{Co} \\
\text { Interv } \\
\text { Diffe }\end{array}$ & $\begin{array}{l}\text { nfidence } \\
l \text { of the } \\
\text { rence }\end{array}$ & $\mathrm{t}$ & $\mathrm{df}$ & $\begin{array}{l}\text { Sig. } \\
(2-\end{array}$ \\
\hline & & & & & & Lower & Upper & & & \\
\hline Pair 1 & Immersion & $\begin{array}{c}\text { Ra before - Ra } \\
\text { after }\end{array}$ &,- 64733 & 44791 &, 08178 &,- 81459 &,- 48008 & $-7,916$ & 29 & ,000 \\
\hline Pair 2 & Immersion & $\begin{array}{c}\text { Rz before - Rz } \\
\text { after }\end{array}$ & $-3,57800$ & 4,40381 &, 80402 & $-5,22241$ & $-1,93359$ & $-4,450$ & 29 & ,000 \\
\hline Pair 3 & $\begin{array}{c}\text { Immersion + } \\
\text { Ultrasound }\end{array}$ & $\begin{array}{c}\text { Ra before - Ra } \\
\text { after }\end{array}$ &,- 61333 & ,70260 &, 12828 &,- 87569 &,- 35098 & $-4,781$ & 29 & ,000 \\
\hline Pair 4 & $\begin{array}{c}\text { Immersion + } \\
\text { Ultrasound }\end{array}$ & $\begin{array}{c}\text { Rz before - Rz } \\
\text { after }\end{array}$ & $-4,24367$ & 4,34046 & ,79246 & $-5,86442$ & $-2,62291$ & $-5,355$ & 29 & ,000 \\
\hline
\end{tabular}

S.D.= Standard Deviation, $\mathbf{R a}=$ Arithmetic average of absolute values, $\mathbf{R z}=$ Average distance between the highest peak and lowest valley in each sampling length 
Other treatment followed the similar trend suggesting that none of the samples had any significant effect of application ultrasound along with the soaking.

Based on the findings in this work it appears that such environmentally friendly dye extract with root of can be effectively used without having any adverse effect on surface quality of eastern redcedar samples. As stated previously eastern redcedar is an invasive and underutilized species in Oklahoma and surrounding states. Using such green dyeing materiel for finishing of furniture and cabinet units made from eastern redcedar will not only result in value-added products but also will require less amount of finishing material due to having smooth surface of the substrate material.

\section{Conclusive}

Based on the findings in this work it appears that natural dye from madder root could have a potential to be used as green finishing material without having any adverse influence on surface quality of substrate material as eastern redcedar used in this work. Addition of ferrous sulfate $\mathrm{Fe}_{2}\left(\mathrm{SO}_{4}\right)_{3} .7 \mathrm{H}_{2} \mathrm{O}$ and alum $\mathrm{KAl}_{2}\left(\mathrm{SO}_{4}\right)_{3} \cdot 18 \mathrm{H}_{2} \mathrm{O}$ in dye solution also did not create and problems regarding surface quality of the samples. In further studies it would be desirable to evaluate bonding strength and glueability of eastern redcedar and other species finished with such root dye to have a better understanding of their properties so that they can be utilized with more efficiency.

\section{References}

Angelini L.G, Pistelli L., Belloni P, Bertoli A and Panconesi S. 1997. Rubia tinctorum a Source of Natural Dyes: Agronomic Evaluation Quantitative Analysis of Alizarin and Industrial Assays. Industrial Crops and Products, 6: 303311.

Davis P.H. 1982. Flora of Turkey and the East Aegean Islands. Edinburgh University Press, ISBN: 0852243960, Volume 07. p947.

Billmeyer F.W.J and Saltzman M. 1991. Principles of color technology. John Wileyand Sons. New York. p240.

Goktas O, Duru E.M, Yeniocak M and Ozen E. 2008. Determination of the Color Stability of an Environmentally Friendly Wood Stain Derived from Laurel (Laurus nobilis L.) Leaf Extracts Under UV Exposure. Forest Products Journal, 58 (1/2):77-80.

Goktas O, Ozen E, Duru M.E and Alma H. 2009b. Determination of the Color stability of an environmentally-friendly wood stain from saffron (Crocus sativus L.) exstracts under uv exposure. Wood Research. 54(4): 111-118.

Goktas O, Ozen E, Baysal E, Mammadov R, Alma H and Sonmez A. 2009a. Color stability of wood treated with maddet rcot (Rubia tinctorium) extract after lightfastness test, Wood Res, 54(1): 37-44.

Hiziroglu S and Holcomb R. 2005. Some of the Properties of Three-Layer Particleboard Made from Eastern Redcedar. Journal of Building and Environment. Elsevier Science. 40(5): 719-723

Hiziroglu S. 1996. Surface Roughness Analysis of Wood Composites: A Stylus Method. Forest Products Journal. 46(7/8):67-72. Forest Products Laboratory, Wood Handbook. USDA Forest Service.

Hiziroglu S, Holcomb R and Wu Q. 2002. Manufacturing Particleboard from Eastern Redcedar. Forest Products Journal. 52(7/8): 72 76

Hiziroglu S, Anwar U.M.K, Hamdan H, and TAHIR P.M.D. 2008. Evaluation of Surface Quality of Some Malaysian Species as Function of Outdoor Exposure. Journal of Materials Processing Technology, Elsevier Science. 199: 156-162.

Kasemsiri P, Hiziroglu S and Rimdusit S. 2012. Characterization of Heat Treated Eastern Redcedar (Juniperus virginiana L.) Journal of Material Processing Technology. 212 (6): 13241330.

McLaren. K. 1983. The Color Science of Dyes and Pigments, Bristol,AdamHilger Ltd.

Satoshi S and Hiziroglu S. 2010. Evaluation of shear strength of Japanese Wood Species as Function of Surface Roughness. Forest Products Journal. 60(4):400-404

Singh R, Jain A, Panwar S, Gupta D and Khare S.K. 2005. Antimicrobial Activity of Some Natural Dyes, Dyes and Pigments, 66: 99102.

Sivakumar, V, and Rao, P. G. 2003. Studies on the use of power ultrasound in leather dyeing. 10(2): 85-94.

Sivakumar V, Lakshmi Anna J, Vijayeeswarri J and Swaminathan G. 2009. Ultrasound Assisted Enhancement in Natural Dye Extraction from Beetroot for Industrial Applications and Natural Dyeing of Leather. Ultrasonics Sonochemistry 16: 782-789.

Tsatsaroni E, Liakopoulou $\mathrm{K}$ and Eleftheriadis M.I. 1998. Comparative Study of Dyeing Poperties of Two Yellow Natural Pigments-Effect of Enzymes and Proteins. Dyes and Pigments 37(4): 307-315.

Wang L and Weller C.L. 2006. Recent advances in extraction of nutraceuticals from plants," Trends in Food Science and Technology.17(6):300-31. 